\title{
Satisfaction across urban consumers of smallholder-produced teak (Tectona grandis L.f.) poles in South Benin
}

Augustin K.N. Aoudji ${ }^{a^{*}}$, Anselme Adégbidi ${ }^{\mathrm{a}}$, Jean C. Ganglo ${ }^{\mathrm{b}}$, Valentin Agbo ${ }^{\mathrm{a}}$, Armand S.I. Yêvidé $^{\mathrm{b}}$, Charles De Cannière ${ }^{\mathrm{c}}$, Philippe Lebailly ${ }^{\mathrm{d}}$

a Département d'Economie, de Socio-Anthropologie et de Communication pour le développement rural, Faculté des Sciences Agronomiques, Université d'Abomey-Calavi, 01 BP 526 Cotonou, Bénin

${ }^{\mathrm{b}}$ Département d'Aménagement et de Gestion de 1'Environnement, Faculté des Sciences Agronomiques, Université d'Abomey-Calavi, 01 BP 526 Cotonou, Bénin

${ }^{\mathrm{c}}$ Service de Lutte biologique et Ecologie spatiale, Ecole Interfacultaire de Bioingénieurs, Université Libre de Bruxelles, Avenue F.D. Roosevelt 50 - CP 160/12, B-1050 Bruxelles, Belgique

${ }^{\mathrm{d}}$ Unité d'Economie et Développement Rural, Université de Liège - Gembloux Agro-Bio Tech, Passage des Déportés 2 - 5030 Gembloux, Belgique

*Corresponding author: Tel.: +229 97481280; E-mail: augustin.aoudji@ gmail.com 


\begin{abstract}
The study used the expectancy-disconfirmation framework to investigate the satisfaction among urban consumers of teak pole in South Benin, so as to identify the areas where interventions are needed to secure market opportunity for smallholder forestry. A survey was conducted in five cities; and 223 household-heads were interviewed using systematic sampling, with a random start. Data were collected on socio-demographic characteristics, teak pole consumption forms, behaviour patterns, and motivations. Respondents also rated their expectations and perceptions for a set of nine attributes on a 7 points Likert scale. Hierarchical ascending cluster analysis was performed to identify consumer segments; and satisfaction level was analysed per segment, by determining the gap between expectations and perceptions, for all attributes. Four consumer segments were identified; and sociodemographic profiles differed across those segments. Competitive price was an important purchasing motivation across the identified segments. Consumers were dissatisfied with price, availability, knot frequency, bending, length, hardness, and durability of teak pole. The efforts to meet the consumer expectations should be concentrated on building farmers' capacity in silvicultural management, and ensuring the availability of good planting material. The issue of competitive price might be addressed, through the improvement of the overall efficiency in the value chain.
\end{abstract}

Keywords: consumer, satisfaction, profile, smallholder forestry, teak pole, marketing. 


\section{Introduction}

Consumer satisfaction is viewed as a performance indicator in business, and has become a critical objective for firms and industries (Anderson, 1994; Anderson and Sullivan, 1993; Coughlan et al., 2001). It has been empirically shown that the better an industry meets the consumer needs, the more likely those consumers will buy its products (Fold and Gough, 2008). Therefore, customer satisfaction is often associated with improved profitability in business (Hauser et al., 1994). A critical issue to marketing organisations is to understand what consumers appreciate in their products, and to effectively and efficiently translate these needs into tangible products and service offerings (van den Heuvel et al., 2007). Measuring consumer satisfaction enables to identify areas where efforts are needed to improve performance. This is important to support smallholder forestry - meaning here, the multipurpose management of small woodlots by smallholder farmers in developing countries (Harrison et al., 2002).

Smallholder forestry is a promising option to meet the demand for forest products and services in developing countries, and is widely viewed as an opportunity to improve the livelihoods of smallholder farmers (Anyonge and Roshetko, 2003; Scherr, 2004). However, the ability to capture this potential depends on the extent to which smallholder farmers can meet market needs. Efforts to enhance small-scale timber production have often focused on tree planting, while the products and their marketing have received little attention (Anyonge and Roshetko, 2003; Russell and Franzel, 2004; Scherr, 2004). Smallholder farmers often plant and manage trees without information about buyers requirements, so that farm-grown timber is often of inadequate quality (Anyonge and Roshetko, 2003; Nawir et al., 2007). This results in low returns to farmers (Maldonado and Louppe, 1999; Nawir et al., 2007), since the price of a product often depends on its quality (Stiglitz, 1987). Intermediaries are also receiving low price, as they collect low quality wood from farmers (Nawir et al., 2007). Therefore, all agents involved in a given value chain can benefit from satisfying market needs. The design of policy to support smallholder forestry requires up-to-date information on the market. So far, unfortunately, we lack comprehensive studies on the consumption of service wood - meaning here, unprocessed timber used variously in small substructures in developing countries. Previous investigation on timber consumption focused on high quality timber (Smorfitt et al., 2002), and did not include consumer satisfaction.

The objective of this study was to assess the satisfaction across urban consumers of smallholder-produced teak (Tectona grandis L.f.) pole in South Benin. Teak planting by 
smallholder farmers in South Benin developed from the 1970s. These plantations are managed by coppicing, and targeted to the production of pole - i.e., service wood with diameter ranging from 5 to $15 \mathrm{~cm}$. Smallholder-produced teak pole is commercialised, and used as service wood in metropolitan regions. The current study generates the market information necessary for timber value chain agents in South Benin to develop appropriate silvicultural management and marketing service, in order to take advantage of domestic timber markets. The rapid growth of urban population in most developing countries (UNDP, 2009), with the resulting demand for service wood represents an opportunity for the agents in farm-grown timber value chains, if they can meet market requirements.

The assessment of consumer satisfaction used the expectancy-disconfirmation framework. This model involves two factors, namely expectations and perception. Expectations are understood as the attributes consumers are seeking while purchasing the product (Anderson, 1994; Gupta and Stewart, 1996; Taylor, 1997), whereas perception - or the perceived performance - represents the consumer evaluation of the product (Kelley and Turley, 2001; Ragaert et al., 2004). The model assumes that the consumer has some standard of comparison in mind before purchasing the product. After consumption, the perceived performance is compared to the expectations. Perceived performance that exceeds expectations leads to satisfaction, while performance that falls short of expectations is dissatisfying (Oliver, 1980; Taylor, 1997). Therefore, the satisfaction level experienced by consumers derives from the gap between expectations and perception.

To investigate consumer satisfaction, we assumed heterogeneity across them, as highlighted by previous studies (e.g., Bock and Uncles, 2002; Thompson et al., 2009), so that we performed a segmentation to identify different groups or segments of teak pole consumers. It had been argued that clustering consumers into segments with similar characteristics can provide a better understanding of consumption patterns (Bruns $\varnothing$ et al., 2002). Another rationale supporting consumer segmentation is that it might be more profitable to treat certain types of consumers in different ways than to treat all of them uniformly; so that useful segmentations improve business performance (Bock and Uncles, 2002). Consumer are usually characterised based on their socio-demographic profile (Kilchling et al., 2009; Ngapo et al., 2004), their behaviour patterns (Verbeke and Vackier, 2004; Santosa and Guinard, 2011), and their motivations (Cameron and Galloway, 2005; Close and Kukar-Kinney, 2010; Ragaert et al., 2004). It was hypothesised that there are different segments of teak pole consumers which 
differ in their socio-demographic profile, behaviour patterns, and motivations. It was also asserted that smallholder-produced teak pole meets consumer needs.

The remainder of this paper is organised as follows. In the next section, we present the research methodology. Results appear in section 3, and the discussion of those results is done in section 4. In the last section, we summarise the main conclusions, the related policy recommendations, and avenue for future researches.

\section{Methods}

\subsection{Sampling and data collection}

A consumer survey was carried out in five major cities in South Benin, namely Cotonou, Abomey-Calavi, Porto-Novo, Sèmé-Kpodji, and Ouidah (Fig. 1).

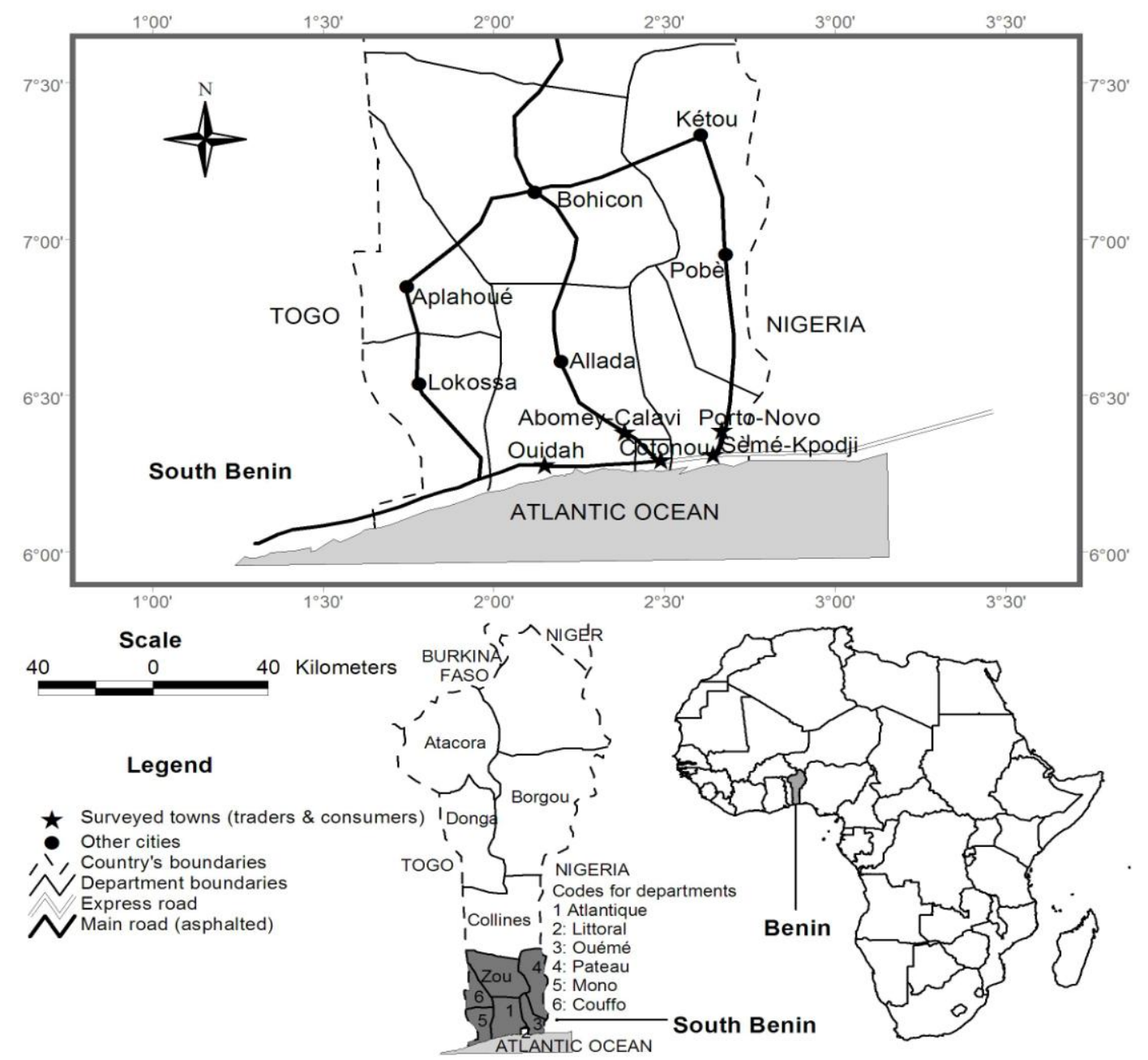

Fig. 1. Map of South Benin.

The map at the top shows the region where smallholder teak plantations developed the most in Benin; at the bottom, the location of the region on the map of Benin is highlighted (left), and Benin is positioned on a map of Africa (right). Teak plantations are encountered to small extent beyond the region presented here. 
Two enumerators were enrolled and trained to data collection that took place between May and June 2010. The sampling was intended to randomly select houses, for household heads interviews. In Benin's administrative structure, towns are subdivided in districts (lower administrative entities), with a total of 25 urban districts in the five cities under study. All those districts were covered by the study, and crossroads were chosen as starting points for systematic sampling among residents. First, three crossroads were randomly selected per district, and for each of them, one street connected to it was randomly selected. Then, all houses in the selected streets were assigned a number. Last, three (3) houses were selected per street, for household heads interviews (one respondent per house), by using systematic sampling procedure (see Giannelloni and Vernette, 2001). This led to a sample of 225 respondents ${ }^{1}$, but two of them were excluded from analyses because of incoherent responses. Face-to-face interviews were used to collect data with a standardised questionnaire. At the beginning, the objectives of the study were presented, and data confidentiality was assured, so as to encourage respondents to provide outspoken answers.

First, the socio-demographic characteristics of the respondents were recorded. At this point, ownership of motorbike, car, and house was recorded as indicators of wealth status, so as to substitute income that respondents were reluctant to disclose. Second, the respondents provided information about teak pole consumption. They were to state their interest in teak pole as service wood, and to specify whether they have ever used this product, and if so how often, and the various consumption forms. Participants could choose from 12 listed consumption forms identified during the exploratory study. Respondents were provided with photographic illustrations of those consumption forms, to ensure answer reliability. In addition, we recorded whether respondents were using any substitute material to teak pole. Third, respondents were to rank four motivations selected from an exploratory study, namely the price, the quality, the suitability, and the easy availability of teak pole. Next, behaviour patterns were recorded. At this point, respondents provided details about the duration since the last purchase of teak pole, the decision-making process, the source of supply, the person responsible for purchase, the criteria underlying the selection of a sale venue, the quantity of teak pole purchased for the latest consumption, and the amount spent for that purchase. The last two items of the questionnaire were expectations and perception. With regard to expectations, the respondents rated the importance of a set of nine attributes of smallholder-

\footnotetext{
${ }^{1}$ This figure is obtained as follows: 25 urban districts $\times 3$ crossroads per district $\times 1$ street per crossroad $\times 3$ respondents per street.
} 
produced teak poles, by using a 7 points Likert scale, ranging from 1 (not at all important) to 7 (very important). Likert scale is used to measure the degree to which people agree or disagree with a statement (e.g., Kelley and Turley, 2001; Shim et al., 2001). The attributes submitted to respondents were selected from the exploratory study; these included 'competitive price', 'easily available', 'low knot frequency', 'no significant bending', 'long enough', 'diversified diameter sizes', 'convenient humidity', 'hard', and 'durable'. To assess perception, the same attributes were used in the form of statements. Respondents were to give their agreement with these statements, on a 7 points Likert scale, ranging from 1 (strongly disagree) to 7 (strongly agree).

\subsection{Data processing and analysis}

\subsubsection{Segmenting and profiling consumers}

Hierarchical ascending cluster analysis was performed to identify consumer segments. This was done based on Ward's method, by using SPSS (Statistical Package for the Social Sciences), version 16. The classificatory variables included teak pole consumption forms. Binary codification (presence/absence) was used for all those variables. The number of consumer segments was chosen, based on the distance between clusters and the profile that resulted from the dendrogram (Ngapo et al., 2004). The identified consumer segments were profiled based on the socio-demographic characteristics, and behaviour patterns. The sociodemographic profiles were described based on gender, age, education level, profession, and wealth status (ownership of motorbike, car, and house). Chi-Square test for equality of distributions (Dagnelie, 1975) was performed, to test for the variation of socio-demographic and behaviour characteristics across consumer segments. The motivations for teak pole consumption were generated with their respective priority ranking. In addition, the uniformity level of motivation ranking within each consumer segment was assessed, based on Kendall's test of concordance, as performed by Dossabhoy and Berger (2002).

\subsubsection{Assessment of consumer satisfaction}

The first stage consisted in identifying the attributes that were important to consumers. An attribute is important if its average score in expectations equals at least the midpoint of the 7

\footnotetext{
${ }^{2}$ During the exploratory study, this attribute was stated by consumers as 'resistant to termites and other damaging insects'. By referring to wood property, the resistance to termite attacks relates to wood durability (e.g., Arango et al., 2006).
} 
points Likert scale (Kelley and Turley, 2001) which in our case equals 4. Important attributes list was generated, by performing Student's $t$ test of conformity on each attribute, 4 being the reference value. With respect to satisfaction, the following rule was used: consumers are satisfied for a given attribute if the average score in the perception $\left(\mu_{\mathrm{p}}\right)$ exceeds the score in the expectations $\left(\mu_{\mathrm{e}}\right)$. This was checked by performing Student's $t$ test of mean comparison on paired sample; the null hypothesis was $\mathrm{H}_{0}: \mu_{\mathrm{p}}-\mu_{\mathrm{e}} \leq 0$. In addition, one-way ANOVA was performed, to test for the difference between consumer segments, with respect to expectations and perception of the various attributes.

\section{Results}

\subsection{Characteristics of the sample}

The sample included a total of 223 respondents. Those respondents were made up of two groups consisting of 13 persons who have never purchased teak pole previously, and 210 who have already purchased and used teak pole for various purposes. The latter group was considered as teak pole consumers. Of the 13 respondents who have never used the product, 12 showed interest in teak pole, and one who preferred substitute materials was not interested in teak pole. Only the 210 actual teak pole consumers have been considered in subsequent analyses, and the characteristics presented hereafter are theirs.

The gender balance of the sample was dominated by men ( $71.9 \%$ men and $28.1 \%$ women).

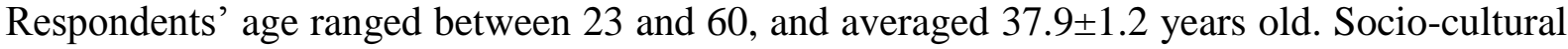
background was fairly diversified and included twenty (20) ethnic groups from Benin, and citizens from other West African countries such as Niger and Mali. Professional background, though diversified, was dominated by craftsmen (31.0\%), employees (33.8\%) and petty traders (26.2\%). The sample also included self-entrepreneurs and professionals (3.3\%), unemployed and trainees (1.4\%), students $(1.0 \%)$, and retired people (3.3\%). With respect to education background, the sample included $16.7 \%$ of respondents who did not attend school. The percentage of respondents according to education level was $21.4 \%$ for primary school, $42.4 \%$ for secondary school, and $19.5 \%$ who reached university degree. About the marital status, the majority of the respondents were married (83.3\%), but there was also an important share of single men and women (14.3\%). The remainder included widowed and divorced, $1.0 \%$ and $1.4 \%$ respectively. With regard to wealth indicators, the majority of respondents had got at least a motorbike (75.7\%); $18.1 \%$ of them had got a car, and $37.6 \%$ had a house. 
The distribution of socio-demographic characteristics showed that a wide range of economic classes purchased teak pole.

\subsection{Categories of teak pole and consumption forms}

Smallholder-produced teak pole consists of a diversified range of diameter. This product was differentiated by value chain agents in three main categories according to the diameter: small poles, medium poles, and large poles (Table 1). The unit price recorded in retail outlets in 2010 ranged from XOF 300 to 2500 (USD 0.6 to 5; average exchange rate from $1^{\text {st }}$ May to 30 June 2010 was XOF $1=\operatorname{USD} 0.002^{3}$ ). Eleven (11) different consumption forms of teak pole were found among urban consumers, namely hangar, shack, grass hut, roof structure, stake for building suspended slab, scaffolding, TV aerial support, shelves, electricity transportation, fence, and clothes airer. Some of those consumption forms are specific to the local context, e.g., hangar, shack, stake, TV aerial support, clothes airer, and electricity transportation; so that explanations are provided hereafter, with illustrative photos (Fig. 3). Hangars are small unfenced sheds (Fig. 3a), while shacks are small sheds covered with metal sheets or local material such as raffia (Fig. 3b). Hangars and shacks are often used as workplace by craftsmen and petty traders. By stake, we refer to teak pole used as support in the building of suspended slab (Fig. 3c). TV aerial support is one piece of teak pole to which TV aerial is fixed (Fig. 3d). Clothes airer means a set of teak poles arranged vertically, and supporting strings on which clothes are dried. Electricity transportation involves teak poles supporting wire to connect houses with electricity (Fig. 3e). This occurred in the areas where the public electricity supply network has not yet been settled. The consumption forms depended on the category of pole (Table 1). Quarrying - i.e., the removal of the bark and part of the sapwood to have approximately parallelepipedic shape - was sometimes performed on large poles intended for use in roof structure. Smallholder-produced teak pole was the main service wood used by urban consumers in South Benin. $24.3 \%$ of respondents reported the occasional purchase of substitute materials such as acacia pole, bamboo, rafter, and steel.

\footnotetext{
${ }^{3}$ Source: http://www.exchangerates.org.uk/XOF-USD-exchange-rate-history.html (Access on 20 October 2010).
} 
Table 1. Diameter, unit retail price, and consumption forms of smallholder-produced teak pole in South Benin.

\begin{tabular}{llll}
\hline Category & Diameter $(\mathrm{cm})$ & $\begin{array}{l}\text { Unit retail price in } \\
2010\left(\mathrm{XOF}^{\mathrm{a}}\right)\end{array}$ & \\
\hline Small poles & $5-7$ & $300-500$ & $\begin{array}{l}\text { Electricity transportation, TV } \\
\text { aerial support, shelves, fence, } \\
\text { and clothes airer }\end{array}$ \\
Medium poles & $7-12$ & $600-1200$ & $\begin{array}{l}\text { hangar, shack, stake, grass hut, } \\
\text { roof structure, TV aerial support, } \\
\end{array}$ \\
& & & and scaffolding \\
Large poles & $12-15$ & $1500-2500$ & Roof structure, stake, and shack \\
\hline
\end{tabular}

${ }^{\mathrm{a}}$ The exchange rate during the survey period was XOF $1=$ USD 0.002 .

\subsection{Teak pole market segmentation}

The hierarchical cluster analysis, based on the consumption forms of teak pole, resulted in four segments of teak pole consumers (Fig. 2). The dominant consumption forms in each consumer segment are shown in Table 2. Cluster 3 (35.2\% of the sample), typified as typical users, was associated with the use of teak pole mainly for hangar, shack, shelves, and TV aerial support (Table 2). Cluster 2 (13.3\% of the sample), typified as narrow users, was associated with the use of teak pole for hangar, and electricity transportation to a lesser extent. Cluster 4 (19.0\% of the sample) was typified as diversified users, with eight different consumption forms of teak poles (Table 2). Cloth airer was the single use not encountered among cluster 1 (32.4\% of the sample) which was typified as wide users. TV aerial support was a common use across all consumer segments except the narrow users, while fence and clothes airer represented scarce consumption forms (Table 2). 
Dendrogram using Ward Method

Rescaled Distance Cluster Combine

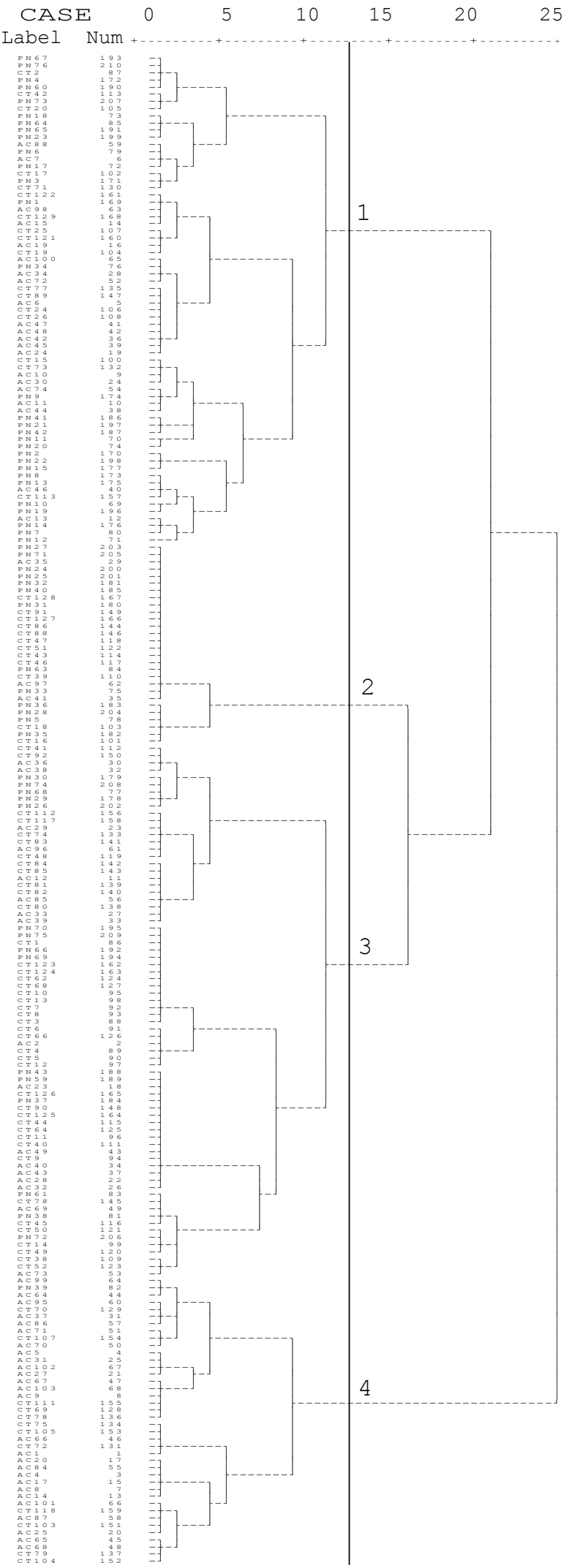

Fig. 2. Hierarchical ascending cluster showing the consumer segments.

The vertical line shows the cluster selection used. 1, 2, 3, and 4 represent clusters' numbering. 
Table 2. Percentage of respondents per consumption form across consumer segments.

\begin{tabular}{lcccc}
\hline & \multicolumn{4}{c}{ Consumer segments } \\
\cline { 2 - 5 } Consumption forms ${ }^{2}(\%)$ & $\begin{array}{c}\text { Typical users } \\
(\mathrm{N}=74)\end{array}$ & $\begin{array}{c}\text { Narrow users } \\
(\mathrm{N}=28)\end{array}$ & $\begin{array}{c}\text { Wide users } \\
(\mathrm{N}=68)\end{array}$ & $\begin{array}{c}\text { Diversified } \\
\text { users (N=40) }\end{array}$ \\
\hline Hangar & 41.9 & 100.0 & 67.6 & 50.0 \\
Shack & 0.0 & 0.0 & 23.5 & 35.0 \\
Grass hut & 0.0 & 0.0 & 8.8 & 100.0 \\
Roof structure & 0.0 & 3.6 & 79.4 & 32.5 \\
Stake for building suspended slab & 0.0 & 0.0 & 5.9 & 30.0 \\
Scaffolding & 83.8 & 0.0 & 58.8 & 0.0 \\
TV aerial support & 1.4 & 21.4 & 36.8 & 90.0 \\
Electricity transportation & 24.3 & 0.0 & 29.4 & 32.5 \\
Shelves & 0.0 & 0.0 & 1.5 & 0.0 \\
Fence & 1.4 & 0.0 & 0.0 & 0.0 \\
Clothes airer & &
\end{tabular}

$\bar{a}$ The percentage for each consumption form, per consumer segment was calculated as follow: Number of respondents who reported the consumption form $\times 100 /$ Total number of respondents in the segment.

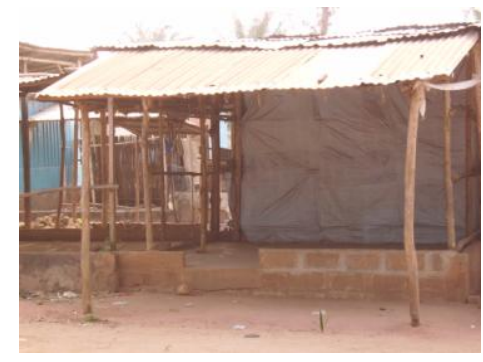

a: Hangar.

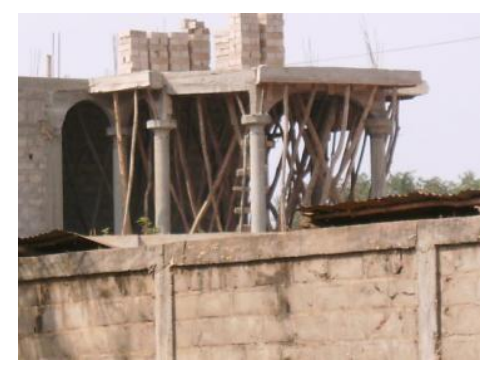

c: Stake for building suspended slab.

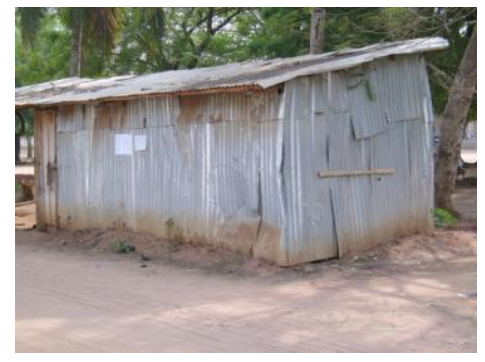

b: Shack.

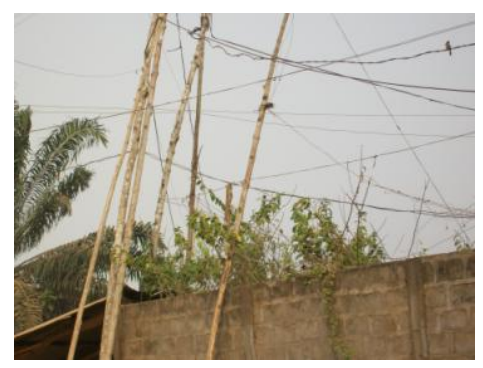

e: Electricity transportation.

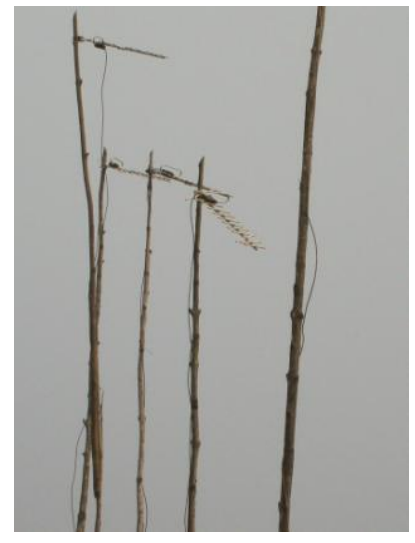

d: TV aerial support.

Fig. 3. Pictures showing consumption forms of smallholder-produced teak pole in South Benin. 


\subsection{Profiling the consumer segments}

\subsubsection{Socio-demographic profile}

The socio-demographic characteristics of teak pole consumers are presented in Table 3. ChiSquare test for equality of distributions showed that frequency distribution varied significantly across consumer segments for gender $\left(\chi^{2}=43.797 ; \mathrm{p}<0.001\right)$, age $\left(\chi^{2}=40.481\right.$; $\mathrm{p}<0.001)$, education level $\left(\chi^{2}=68.492 ; \mathrm{p}<0.001\right)$, and professional background $\left(\chi^{2}=35.379\right.$; $\mathrm{p}<0.001)$. Significantly more women belonged to the segment of narrow users, with a percentage three times higher than the percentage of women in the entire sample. The respective percentage of men and women in the typical users segment was close to the one of the entire sample, confirming this market segment was representative of the average teak pole consumers. On the other hand, diversified and wide users were characterised by the predominance of men. With regard to age, the respondents under 30 years old were more represented in the narrow users segment, while those above 45 were predominant among diversified and wide users. With respect to education level, the illiterates were more represented among the narrow users. On the contrary, the respondents with university degree appeared to be in larger number than the other education levels in the diversified users segment. The segments of typical users and wide users showed similar distribution of education levels, and were characterised by the predominance of respondents with secondary school degree. Professional background was characterised by the predominance of craftsmen and small traders in the typical and narrow users segments, while employees and the other categories were more represented among diversified and wide users. Wealth indicators also showed significant difference across consumer segments for car ownership $\left(\chi^{2}=27.163\right.$; $\mathrm{p}<0.001)$, and house ownership $\left(\chi^{2}=50.825 ; \mathrm{p}<0.001\right)$. A higher proportion of respondents within diversified and wide users segments owned a car and a house. However, no significant dependency was found between consumer clustering and motorbike ownership $\left(\chi^{2}=3.963\right.$; $\mathrm{p}=0.3$ ). The general picture emerging from these results is a differentiation of sociodemographic profile across consumer segments, as hypothesised. 
Table 3. Socio-demographic characteristics of teak pole consumers per market segment.

\begin{tabular}{|c|c|c|c|c|}
\hline \multirow{2}{*}{$\begin{array}{l}\text { Socio-demographic } \\
\text { characteristics }(\%)\end{array}$} & \multicolumn{4}{|c|}{ Consumer segments } \\
\hline & $\begin{array}{l}\text { Typical users } \\
(\mathrm{N}=74)\end{array}$ & $\begin{array}{l}\text { Narrow users } \\
\qquad(\mathrm{N}=28)\end{array}$ & $\begin{array}{l}\text { Wide users } \\
\qquad(\mathrm{N}=68)\end{array}$ & $\begin{array}{r}\text { Diversified } \\
\text { users }(\mathrm{N}=40)\end{array}$ \\
\hline \multicolumn{5}{|l|}{ Gender ${ }^{*}$} \\
\hline Male & 60.8 & 32.1 & 88.2 & 92.5 \\
\hline Female & 39.2 & 67.9 & 11.8 & 7.5 \\
\hline \multicolumn{5}{|l|}{ Age $^{*}$} \\
\hline$\leq 30$ & 25.7 & 42.9 & 25.0 & 7.5 \\
\hline $31-45$ & 70.3 & 46.4 & 39.7 & 50.0 \\
\hline$>45$ & 4.1 & 10.7 & 35.3 & 42.5 \\
\hline \multicolumn{5}{|l|}{ Education level $^{*}$} \\
\hline No schooling & 12.2 & 46.4 & 16.2 & 12.5 \\
\hline Primary & 25.7 & 35.7 & 20.6 & 2.5 \\
\hline Secondary & 51.4 & 14.3 & 50.0 & 30.0 \\
\hline University & 10.8 & 3.6 & 13.2 & 55.0 \\
\hline \multicolumn{5}{|l|}{ Profession $^{*}$} \\
\hline Craftsmen & 40.5 & 42.9 & 26.5 & 12.5 \\
\hline Small traders & 27.0 & 46.4 & 22.1 & 17.5 \\
\hline Employees & 28.4 & 10.7 & 41.2 & 47.5 \\
\hline Other $^{a}$ & 4.1 & 0.0 & 10.3 & 22.5 \\
\hline \multicolumn{5}{|l|}{ Wealth status $^{b}$} \\
\hline Motorbike ownership & 74.3 & 64.3 & 76.5 & 85.0 \\
\hline Car ownership ${ }^{*}$ & 5.4 & 3.6 & 25.0 & 40.0 \\
\hline House ownership ${ }^{*}$ & 10.8 & 21.4 & 64.7 & 52.5 \\
\hline
\end{tabular}

${ }^{a}$ This encompasses self-entrepreneurs and professionals, unemployed, trainees, students, and retired people.

${ }^{b}$ For each wealth indicator, the percentage was calculated per consumer segment as follow: Number of respondents who reported ownership of the item in the segment $\times 100 /$ Total number of respondents in the segment.

* This indicates the variables showing significant variation of frequency distribution across consumer segments, with p-value associated to Chi-Square test of equality of distributions inferior to 0.001 . 


\subsubsection{Behaviour patterns}

The results showed a diversified range of behaviour patterns among consumers (Table 4). The duration since the last purchase of teak pole varied marginally across consumer segments $\left(\chi^{2}=11.530 ; \mathrm{p}=0.073\right)$, similarly to the decision-making process for teak pole purchase $\left(\chi^{2}=12.376 ; \mathrm{p}=0.054\right)$. Two variables showed clear-cut differences of frequency distribution with regard to consumer segments, namely the person responsible for teak pole purchase $\left(\chi^{2}=38.855 ; \mathrm{p}<0.001\right)$, and the quantity of timber purchased $\left(\chi^{2}=25.595 ; \mathrm{p}<0.001\right)$. On the other hand, no variation of frequency distribution across consumer segments was found for teak pole source $\left(\chi^{2}=1.306 ; \mathrm{p}=0.73\right)$, and the criterion underlying the choice of the sale venue $\left(\chi^{2}=1.076 ; \mathrm{p}=0.78\right)$. With respect to the duration since the last purchase, the majority of consumers purchased the product more than 6 months ago, and over one third of the last purchase occurred more than 1 year ago across the market segments. About decision-making, the two predominant processes were consumers' personal initiative, and service providers' advice. Relatives (friends and parents) were also involved, to a lesser extent, in decisionmaking. The importance of personal initiative in decision-making suggested that teak pole as service wood was well known to consumers, and most of them purchased the product consciously. With regard to supply, the majority of consumers bought teak pole from timber traders, but a small share purchased directly from farmers. With respect to the person responsible for the purchase, three cases were found: purchase by the consumer alone, the service provider alone, or both actors together. Noticeably, the segment of narrow users was characterised by the predominance of service providers in the supply. Since timber is a heavy product, its handling is a delicate task for women - the majority of respondents in this segment -, so that they preferred the assistance of service providers to purchase the product. On the other hand, diversified users preferred buying pole together with the service provider. Consumers explained that, accompanying the service provider enabled them to benefit from his expertise for purchasing good quality timber. Meanwhile, it helped preventing any potential cheating behaviour that could occur if the service provider was to handle the purchase alone. The results showed that consumers across the various segments overwhelmingly purchased teak pole from the nearest outlet. The main reason supporting such behaviour is that the transportation cost is cheaper when timber is bought from an outlet close to the consumption place.

The quantities of timber purchased for the last consumption of teak pole, and the amount spent are shown per consumer segment in Table 5. The highest quantities of timber as well as 
amount spent were related to house construction jobs. These included grass hut, roof structure, stake for building suspended slab, and scaffolding. Hangar and shacks that were wide consumption forms across consumer segments required 10 to 20 pieces of poles on average; while TV aerial support required only one piece of pole. With regard to electricity transportation, the average quantity of timber used ranged from 1 to 10 , according to the transport distance. Since fence and clothes airer were scarce consumption forms, the related figures might be unrepresentative. No respondent reported shelves as the last consumption form of teak pole. According to our investigations, this required 5 to 10 poles, with an expenditure of XOF 2500-10000 (USD 5-20).

Table 4. Behaviour patterns of smallholder-produced teak pole consumers across segments.

\begin{tabular}{|c|c|c|c|c|}
\hline \multirow[b]{2}{*}{ Behaviour patterns (\%) } & \multicolumn{4}{|c|}{ Consumer segments } \\
\hline & $\begin{array}{l}\text { Typical users } \\
\qquad(\mathrm{N}=74)\end{array}$ & $\begin{array}{l}\text { Narrow users } \\
\qquad(\mathrm{N}=28)\end{array}$ & $\begin{array}{l}\text { Wide users } \\
(\mathrm{N}=68)\end{array}$ & $\begin{array}{c}\text { Diversified } \\
\text { users }(\mathrm{N}=40)\end{array}$ \\
\hline \multicolumn{5}{|l|}{ Duration since the last use } \\
\hline Less than 6 months ago & 36.5 & 42.9 & 42.6 & 15.0 \\
\hline $6-12$ months & 27.0 & 21.4 & 23.5 & 25.0 \\
\hline More than 1 year & 36.5 & 35.7 & 33.8 & 60.0 \\
\hline \multicolumn{5}{|l|}{ Purchase decision (first use) } \\
\hline Parent/friend advice & 17.6 & 10.7 & 8.8 & 7.5 \\
\hline Service provider's advice & 31.1 & 57.1 & 33.8 & 52.5 \\
\hline Personal initiative & 51.4 & 32.1 & 57.4 & 40 \\
\hline \multicolumn{5}{|l|}{ Responsible of purchase $^{*}$} \\
\hline Service provider & 24.7 & 59.3 & 34.8 & 7.7 \\
\hline Consumer or a relative & 47.9 & 33.3 & 33.3 & 25.6 \\
\hline $\begin{array}{l}\text { Consumer or a relative with the } \\
\text { service provider }\end{array}$ & 27.4 & 7.4 & 31.8 & 66.7 \\
\hline \multicolumn{5}{|l|}{ Teak pole source } \\
\hline From planters & 6.8 & 7.1 & 7.4 & 12.5 \\
\hline From traders & 93.2 & 92.9 & 92.6 & 87.5 \\
\hline \multicolumn{5}{|l|}{ Criterion of choice of sale venue } \\
\hline From a particular supplier & 11.0 & 11.1 & 13.3 & 17.5 \\
\hline From the closer depot & 89.0 & 88.9 & 86.7 & 82.5 \\
\hline
\end{tabular}

\footnotetext{
This indicates the variables showing significant variation of frequency distribution according to consumer segments. In all cases, p-value associated to Chi-Square test of equality of distributions was inferior to 0.001 .
} 
Table 5. Average quantity of teak pole purchased and average expenditure for the last consumption, per consumer segment.

\begin{tabular}{|c|c|c|c|c|c|c|c|c|}
\hline \multirow{2}{*}{ Consumption forms } & \multicolumn{2}{|c|}{ Typical users } & \multicolumn{2}{|c|}{ Narrow users } & \multicolumn{2}{|c|}{ Wide users } & \multicolumn{2}{|c|}{ Diversified users } \\
\hline & $\begin{array}{c}\text { Quantiti } \\
\text { es }\end{array}$ & $\begin{array}{l}\text { Expendi } \\
\text { ture }^{\text {a }}\end{array}$ & $\begin{array}{c}\text { Quantiti } \\
\text { es }\end{array}$ & $\begin{array}{l}\text { Expendi } \\
\text { ture }\end{array}$ & $\begin{array}{c}\text { Quantiti } \\
\text { es }\end{array}$ & $\begin{array}{l}\text { Expendi } \\
\text { ture }\end{array}$ & $\begin{array}{c}\text { Quantiti } \\
\text { es }\end{array}$ & $\begin{array}{l}\text { Expendi } \\
\text { ture }\end{array}$ \\
\hline Hangar & 13 & 10868 & 12 & 9559 & 16 & 12345 & 12 & 10500 \\
\hline Shack & 18 & 15386 & - & - & 19 & 14000 & 15 & 11250 \\
\hline Grass hut & 30 & 20000 & - & - & 20 & 25000 & 22 & 19222 \\
\hline Roof structure & $-{ }^{b}$ & - & - & - & 37 & 37917 & 50 & 38333 \\
\hline $\begin{array}{l}\text { Stake for suspended } \\
\text { slab (purchase) }\end{array}$ & - & - & - & - & 200 & 100000 & 383 & 225000 \\
\hline $\begin{array}{l}\text { Stake for suspended } \\
\text { slab (hire) }{ }^{c}\end{array}$ & - & - & - & - & - & - & 600 & 130000 \\
\hline Scaffolding & - & - & - & - & 150 & 80000 & - & - \\
\hline TV aerial support & 1 & 1227 & - & - & 1 & 1392 & 1 & 1656 \\
\hline $\begin{array}{l}\text { Electricity } \\
\text { transportation }\end{array}$ & 5 & 6000 & 10 & 7000 & 7 & 3833 & 1 & 700 \\
\hline Fence & - & - & - & - & 20 & 10000 & - & - \\
\hline Clothes airer & 3 & 2500 & - & - & - & - & - & - \\
\hline
\end{tabular}

Note: It was delicate to perform comparative statistical analysis here, because not all consumption forms were represented across consumer segments.

${ }^{\text {a }}$ Expenditure figures are in local currency (XOF). The exchange rate during the survey period was XOF $1=$ USD 0.002 .

${ }^{b}$ - means that no respondent in this segment has reported the item as the last consumption form of teak pole.

${ }^{c}$ Since the building of suspended slabs required large quantities of teak pole, certain consumers preferred hiring the product (XOF 100-200 per pole), in order to reduce expenditures. The poles were brought back to the traders after completion of the job.

\subsubsection{Consumers' motivations}

The motivation ranking was uniform for the wide users, the narrow users, and the typical users. Buying at a competitive price was ranked as the first most important motivation, followed by suitability and easy availability. On the other hand, suitability was ranked first most important motivation by the diversified users, followed by price. Surprisingly, timber quality was the less important motivation across consumer segments (Table 6). Consumers made a subtle difference between product suitability and quality. For them, suitability refers to whether the material can serve for the targeted use, even if it will provide little comfort and deteriorate after a short period of time. By contrast, quality refers to a high standard product 
that can provide more comfort and last over the time. Kendall's test of concordance showed a high level of agreement among respondents about the ranking of motivations, except in the segment of wide users; even in that case, however, the coefficient of concordance was close to 0.5 (Table 7). Contrary to our assertion, the results showed, to some extent, similarities between segments, with respect to motivations underlying teak pole purchase.

Table 6. Motivations across smallholder-produced teak pole consumer segments.

\begin{tabular}{cllll}
\hline Motivation & \multicolumn{4}{c}{ Consumer segments } \\
\cline { 2 - 5 } ranking & Typical users (N=74) & Narrow users (N=28) & Wide users (N=68) & Diversified users (N=40) \\
\hline $1^{\text {st }}$ & Price (1.5) & Price (1.5) & Price (1.6) & Suitability (1.5) \\
$2^{\text {nd }}$ & Suitability (2.2) & Suitability (2.0) & Suitability (2.1) & Price (2.2) \\
$3^{\text {rd }}$ & Easy availability (2.4) & Easy availability (3.1) & Easy availability (2.7) & Easy availability (2.5) \\
$4^{\text {th }}$ & Quality (3.9) & Quality (3.5) & Quality (3.7) & Quality (3.8) \\
\hline
\end{tabular}

${ }^{\mathrm{a}}$ The bracketed figures are the average rank of each motivation.

Table 7. Results of Kendall's concordance test on motivation ranking within teak pole consumer segments.

\begin{tabular}{lcccc}
\hline \multirow{2}{*}{ Parameters } & \multicolumn{4}{c}{ Consumer segments } \\
\cline { 2 - 5 } & Typical users & Narrow users & Wide users & Diversified users \\
\hline $\mathrm{N}$ & 74 & 28 & 68 & 40 \\
Kendall's W & 0.606 & 0.537 & 0.482 & 0.562 \\
Chi-Square & 134.465 & 45.129 & 98.276 & 67.500 \\
df & 3 & 3 & 3 & 3 \\
Asymp. Sig. & 0.000 & 0.000 & 0.000 & 0.000 \\
\hline
\end{tabular}

${ }^{\mathrm{a}}$ Kendall's coefficient of concordance $(0=$ no agreement, $1=$ total agreement $)$.

\subsection{Satisfaction across consumer segments}

The comparison of expectations across consumer segments showed different pictures from one attribute to another. The average expectation scores (Table 8) varied across consumer segments for the following attributes of teak pole: 'low knot frequency', 'no significant bending', 'long enough', 'convenient humidity', 'hard', and 'durable', with p-value from oneway ANOVA inferior to 0.05 . Student's $t$ test of conformity revealed that eight attributes were important to consumers across segments, with a mean value higher than 4. 'Convenient humidity content' was the only attribute with a mean value significantly lower than 4 (Table 
8). Similarly to expectations, variability of perception across consumer segments depended on the attribute considered. The following attributes differed across consumer segments: 'competitive price', 'easily available', 'diversified diameter sizes', 'convenient humidity', and 'durable' (p-value from one-way ANOVA inferior to 0.05).

The comparison between expectations and perception showed dissatisfaction in all consumer segments (Table 8). Among the criteria that matter to them, consumers were satisfied only with the attribute 'diversified diameter sizes of pole', for all segments. In addition, the narrow users were satisfied with the low knot frequency on the poles. The attributes requiring effort for improved consumer satisfaction were as follows: 'competitive price', 'easily available', 'low knot frequency', 'no significant bending', 'long enough', 'hard', and 'durable'. Those attributes were identical for all consumer segments except 'low knot frequency' that was fine with the consumers from the narrow users segment.

Table 8. Gap analysis of the satisfaction level across teak pole consumer segments.

\begin{tabular}{|c|c|c|c|c|c|c|c|c|}
\hline \multirow{2}{*}{ Attributes } & \multicolumn{4}{|c|}{ Expectations } & \multicolumn{4}{|c|}{ Perception } \\
\hline & $\mathrm{TU}$ & $\mathrm{NU}$ & $\overline{W U}$ & $\overline{\mathrm{DU}}$ & $\mathrm{TU}$ & $\mathrm{NU}$ & $\overline{W U}$ & $\overline{\mathrm{DU}}$ \\
\hline Competitive price & $6.6 a$ & $6.7 \mathrm{ab}$ & $6.7 \mathrm{a}$ & $6.7 \mathrm{a}$ & $5.2 b^{*}$ & $5.0 b^{*}$ & $4.8 a^{*}$ & $5.2 b^{*}$ \\
\hline Easily available & $5.8 \mathrm{a}$ & $5.8 \mathrm{a}$ & $5.9 \mathrm{a}$ & $5.8 \mathrm{a}$ & $5.0 \mathrm{~b} *$ & $4.8 b^{*}$ & $5.3 \mathrm{a}^{*}$ & $5.1 \mathrm{ab} *$ \\
\hline Low knot frequency & $5.2 \mathrm{ab}$ & $4.7 b$ & $5.4 \mathrm{a}$ & $5.0 \mathrm{ab}$ & $4.0 \mathrm{a}^{*}$ & $4.3 \mathrm{a}$ & $4.2 \mathrm{a}^{*}$ & $3.9 a^{*}$ \\
\hline No significant bending & $6.5 \mathrm{a}$ & $6.5 \mathrm{a}$ & $6.5 \mathrm{a}$ & $6.8 b$ & $4.7 a^{*}$ & $4.8 \mathrm{a}^{*}$ & $4.6 \mathrm{a}^{*}$ & $4.7 a^{*}$ \\
\hline Long enough & $6.6 \mathrm{a}$ & $6.4 b$ & $6.6 a$ & $6.7 \mathrm{a}$ & $5.4 a^{*}$ & $5.4 a^{*}$ & $5.3 \mathrm{a}^{*}$ & $5.4 a^{*}$ \\
\hline Diversified diameter sizes & $4.9 \mathrm{a}$ & $4.8 \mathrm{a}$ & $5.1 \mathrm{a}$ & $5.1 \mathrm{a}$ & $5.0 \mathrm{ab}$ & $5.3 \mathrm{bc}$ & $4.8 \mathrm{a}$ & $5.7 \mathrm{c}$ \\
\hline Convenient humidity & $3.4 \mathrm{a}$ & $3.6 \mathrm{a}$ & $3.5 \mathrm{a}$ & $2.1 \mathrm{~b}$ & $3.8 \mathrm{a}$ & $4.1 \mathrm{a}$ & $3.9 \mathrm{a}$ & $2.8 \mathrm{~b}$ \\
\hline Hard & $6.5 \mathrm{a}$ & $6.6 \mathrm{ab}$ & $6.6 \mathrm{ab}$ & $6.9 b$ & $4.6 a^{*}$ & $4.8 \mathrm{a}^{*}$ & $4.7 a^{*}$ & $4.8 \mathrm{a}^{*}$ \\
\hline Durable & $6.5 \mathrm{a}$ & $6.6 a$ & $6.6 \mathrm{a}$ & $6.9 \mathrm{~b}$ & $4.2 b^{*}$ & $4.6 \mathrm{a}^{*}$ & $4.3 \mathrm{ab}^{*}$ & $4.4 \mathrm{ab} *$ \\
\hline
\end{tabular}

Note: NU, TU, WU, and DU mean respectively narrow users, typical users, wide users, and diversified users.

$\mathrm{a} ; \mathrm{b}$; and c: For expectations and perception, scores in one row with different letters are significantly different at $\mathrm{p}<0.05$ (one-way ANOVA and post hoc Least Significant Difference test).

* Significance level of Student's $t$ test of mean comparison on paired sample between expectations and perception: means perception consistently inferior to expectations for this attribute in this market segment; all $\mathrm{p}<0.01$. 


\section{Discussion}

\subsection{Consumers segmentation and profiling}

Four segments were identified among urban consumers of smallholder-produced teak pole in South Benin, with a consistent differentiation of socio-demographic profiles across them. By scrutinising simultaneously teak pole consumption forms, socio-demographic profile, and behaviour patterns of consumers, it appeared that the narrow users segment was associated with women, relatively younger than average, who were predominantly small traders and craftsmen. They had low education background and low wealth status, as compared to the typical users. On the other hand, diversified and wide users were characterised by relatively aged consumers, with higher education level, most of them were employees. They showed a diversified range of consumption forms and purchased larger quantities of teak pole, for house construction job (e.g., roof structure and stake for building suspended slab). Compared to the typical users, diversified and wide users were wealthier. House ownership, that was dominant in the wealth status of diversified and wide users, is widely considered as an indicator of higher social status in Benin. On the other hand, the narrow users segment represented a poorer consumer group. For instance, they did not report TV aerial support among teak pole consumption forms, and then they failed to own a TV receiver, contrary to the majority of consumers in the three other segments. As highlighted previously by Scherr (2004), the study confirms the potential for smallholder forestry to supply timber to domestic markets for Benin. The identified consumer segments included a wide range of socio-demographic profiles, from the economically weak classes (e.g., narrow users) to wealthier consumers (diversified and wide users).

Clearly, competitive price represented a strong motivation in the purchase decision of consumers, followed by suitability, and then the availability while quality received less attention. The high ranking for suitability showed that even though consumers gave up quality for affordable price, they were concerned with the adequacy between teak pole and the targeted consumption forms. Our findings are consistent with previous results with respect to the competitive price as strong motivation in consumer behaviour (Cameron and Galloway, 2005; Close and Kukar-Kinney, 2010; Ragaert et al., 2004). With regard to timber consumption, the current results tally to a large extent with previous findings by Smorfitt et al. (2002) on wood consumption by cabinet-makers in Queensland, Australia. Price, consistency of colour and grain (a quality attribute), availability, suitability, and customer request were the factors influencing cabinet-makers decision to use a particular timber for the 
task at hand. However, in contrast with our results, price received the lower rating among the five factors stated above. This contrast might originate from the differences between the populations under study, with respect to wealth status (developing country versus developed country), and the category of timber (rough timber versus processed wood). Since cabinet belongs to the category of furniture, consumers might be more sensitive to comfort to the detriment of price.

\subsection{Satisfaction across consumer segments}

The study raised concerns about smallholder forestry, since consumers across all segments were dissatisfied with the overwhelming majority of the attributes evaluated. Surprisingly, farm-grown teak remained the principal service wood for urban consumers in South Benin, with most of them purchasing the product repeatedly. This finding is consistent with the previous remark that dissatisfied consumers might continue to purchase the product (Gupta and Stewart, 1996). Presumably, this could mean that so far, consumers do not have a better alternative. Another probable reason is that the majority of dissatisfying attributes were related to technical quality which was an ancillary motivation for consumers (cf. section 3.4.3).

Teak timber is often praised for its interesting properties (Pandey and Brown, 2000). Consumers' complaints over hardness and durability might therefore seem surprising. However, a satisfactory explanation has been provided by Haslett et al. (1991) who showed that plantation-grown tropical tree species - teak included - produce wood with properties considerably lower than those from natural stands, for rotations under 20 years. These findings suggest that consumers' complaints over hardness and durability originate from the fact that teak at the growth stage of pole is not yet mature. In the current silvicultural management regime, consisting in coppicing with rotations of 3 to 5 years on average, the harvested timber remains immature, with the predominance of sapwood. With regard to durability, treatments to improve timber resistance against termites and other insects are available (Hwang et al., 2005), including endogenous techniques such as timber painting with waste oil. Since consumers cared about price, further information is required on the cost benefit analysis of the use of such treatments. Apart from the potential impact of silvicultural 
management on the length of teak pole ${ }^{4}$, its rectitude and the knot frequency, a proper genetic material (i.e., provenance) choice might play a relevant role in improving these attributes. Indeed, the provenance influences the technical quality of planted trees (Bhat and Priya, 2004; Miranda and Pereira, 2002). In the specific case of teak in Benin, Azankpan et al. (2009) compared the performance of the two provenances grown locally, namely the local and the Tanzanian provenances, and found that the Tanzanian provenance had higher trunks. Unfortunately, smallholder teak plantations in South Benin have been established predominantly with unsorted material of local provenance. Therefore, efforts to meet market needs should include the building of the capacity of smallholder farmers in the silvicultural management of teak plantation, and the availability of good planting material.

With respect to the 'easy availability', this relates to a closer proximity of retail outlets. Since the settlement of outlets is part of marketing service, any improvement in this field depends on traders' decision, taking into account the potential market and the induced costs by the outlet. This can be promoted, to some extent, by the removal of excessive entry barriers to timber trade, i.e. licence costs. In Benin, licences are required to do business in the forestry sector (logging, trade, and processing activities). The licence is renewed by the forest service each year on holders' request. The renewal costs per licence were estimated at XOF 79500 (USD 159) in 2010. Before starting their business, traders also have to register themselves at the Department of domestic trade, for about XOF 100000 (USD 200) in 2010. Cheaper price is conflicting with consumers' request for improved quality. However, competitive price might be promoted to some extent by general improvement of efficiency within the value chain. This requires efficiency in timber production at farm level - by strengthening farmers' capabilities to implement proper technical itineraries -, and lower marketing costs through improved coordination in the value chain. Regarding the latter point, traders were to seek a new supplier for each purchase of stumpage timber (increased search costs), because farmers had relatively small acreages of plantation $(1.50 \pm 0.31 \mathrm{ha})$, so that they were unable to supply consistent quantities over time. It is argued that collective marketing can enable farmers to overcome this constraint, so as to strengthen coordination between them and traders. This involves support to the development of teak planters association which did not exist during the study period.

\footnotetext{
${ }^{4}$ Only one piece of pole is obtained from a single tree, so that pole length depends basically on the trunk height of the trees. In the framework of a survey carried out among timber traders, we measured pole length in retail outlets and found value ranging generally from 4 to 8 meters.
} 


\section{Conclusions}

The study consisted in segmenting and profiling urban consumers of smallholder-produced teak pole in South Benin, and assessing their satisfaction level. As hypothesised, the consumer segments differed with respect to their socio-demographic profile, but differences in behaviour patterns and motivations were less perceptible. Regarding satisfaction level, the general picture emerging from the study is that consumers were more or less dissatisfied than they would be using alternatives. The attributes on which improvement efforts were required included price competitiveness, easy availability, knot frequency, rectitude, length, hardness, and durability. Since those dissatisfying attributes were almost identical for all consumer segments, a single strategy might be satisfactory to address the consumers' needs. Improving consumer satisfaction depends on the two main agents operating in the value chain, namely smallholder farmers and timber traders. Farmers are concerned as far as the technical quality of teak pole is targeted, while traders are more concerned with the easy availability of the product. Both agents are concerned with the issue of price competitiveness. The results suggested that efforts should be concentrated mainly on strengthening the capacity of teak planters in silvicultural management, for improved technical quality. This involves the availability of good planting material, the transfer of stand management skills, and the shift toward longer rotation. The latter point has to be considered cautiously, because smallholder farmers clearly showed reluctance to long rotations which might decrease their profit. Price competitiveness was a critical issue that could be addressed through the improvement of the overall efficiency in the value chain. Lastly, the reduction of barriers to timber trade is expected to improve the availability of teak pole to urban consumers. The important question is who will take the lead in this action? Even if NGOs could play a significant role in supporting smallholder farmers, this is basically the responsibility of governments, as part of their efforts to capture the potential of smallholder forestry as contributor to rural development and poverty alleviation, and to the provision of forest products and environmental service.

The study showed the need for further researches. Since service providers were playing a critical role in decision-making, it would be interesting to assess their expectations, and perceptions, so as to get a deeper understanding of the market need for farm-grown teak. To ensure competitive price, we need to scrutinise potential paths to improve the overall efficiency in the value chain. Research on policies affecting the value chain and policy changes could also improve efficiency. Lastly, it is also important to assess how effective and 
efficient indigenous methods, such timber painting with waste oil, can improve durability i.e., resistance to termites and other insects.

\section{Acknowledgement}

The study was carried out in the framework of the 'Projet Interuniversitaire Ciblé: Contribution au développement d'une filière de teck au départ des forêts privées du SudBénin (département Atlantique)' the purpose of which was to support the development of a viable teak value chain in South Benin. The Belgian 'Commission Universitaire pour le Développement (CUD)' is gratefully acknowledged for funding the project. Thanks also to Mr Essègbèmon Akpo and anonymous reviewers, for constructive comments on earlier versions of the paper.

\section{References}

Anderson, E.W., 1994. Cross-category variation in customer satisfaction and retention. Marketing Letters 5 (1), 19-30.

Anderson, E.W., Sullivan, M.W., 1993. The antecedents and consequences of customer satisfaction for firms. Marketing Science 12 (2), 125-143.

Anyonge, C.H., Roshetko, J.M., 2003. Farm-level timber production: orienting farmers towards the market. Unasylva 54, 48-56.

Arango, R.A., III, F.G., Hintz, K., Lebow, P.K., Miller, R.B., 2006. Natural durability of tropical and native woods against termite damage by Reticulitermes flavipes (Kollar). International Biodeterioration and Biodegradation 57 (3), 146-150.

Azankpan, J.D., Ganglo, C.J., Zohoun, S., 2009. Performances de deux provenances de teck (Tectona grandis L.f.) au Bénin. Annales des Sciences Agronomiques 12 (1), 55-65.

Bhat, K.M., Priya, P.B., 2004. Influence of provenance variation on wood properties of teak from the western Ghat region in India. IAWA Journal 25 (3), 273-282.

Bock, T., Uncles, M., 2002. A taxonomy of differences between consumers for market segmentation. International Journal of Research in Marketing 19, 215-224.

Brunsø, K., Fjord, T.A., Grunert, K., 2002. Consumers' food choice and quality perception. MAPP Working paper $N^{\circ} 77$. The Aarhus School of Business, Aarhus.

Cameron, D.D., Galloway, A., 2005. Consumer motivations and concerns in online auctions: an exploratory study. International Journal of Consumer Studies 29 (3), 181-192. 
Close, A.G., Kukar-Kinney, M., 2010. Beyond buying: motivations behind consumers' online shopping cart use. Journal of Business Research 63 (9-10), 986-992.

Coughlan, A.T., Anderson, E., Stern, L.W., El-Ansary, A.I., 2001. Marketing channels, Prentice Hall, New Jersey.

Dagnelie, P., 1975. 2nd ed. Théories et méthodes statistiques, 2, Gembloux Agronomic Press, Gembloux, ISBN: 2-87016-010-0.

Dossabhoy, N.S., Berger, P.D., 2002. Business school research: bridging the gap between producers and consumers. Omega 30, 301-314.

Fold, N., Gough, K.V., 2008. From smallholders to transnationals: the impact of changing consumer preferences in the EU on Ghana's pineapple sector. Geoforum 39, 16871697.

Giannelloni, J.-L., Vernette, E., 2001. Etudes de marché, $2^{\mathrm{e}}$ éd. Vuibert, Paris.

Gupta, K., Stewart, D.W., 1996. Customer satisfaction and customer behavior: the differential role of brand and category expectations. Marketing Letters 7 (3), 249-263.

Harrison, S.R., Herbohn, J.L., Niskanen, A.J., 2002. Non-industrial, smallholder, small-scale and family forestry: what's in a name? Small-scale Forest Economics, Management and Policy 1 (1), 1-11.

Haslett, A.N., Young, G.D., Britton, R.A.J., 1991. Plantation grown tropical timbers. 2. properties, processing and uses. Journal of Tropical Forest Science 3 (3), 229-237.

Hauser, J.R., Simester, D.I., Wernerfelt, B., 1994. Customer satisfaction incentives. Marketing Science 13 (4), 327-350.

Heuvel van den, T., Trijp van, H., Woerkum van, C., Renes, R.J., Gremmen, B., 2007. Linking products offering to consumer needs; inclusion of credence attributes and the influence of product features. Food Quality and Preference 18, 296-304.

Hwang, W.J., Kartal, S.N., Shinoda, K., Imamura, Y., 2005. Surface treatment for preventing decay and termite attack in wood using didecyl dimethyl ammonium tetrafluoroborate (DBF) incorporated with acryl-silicon type resin. Holz als Roh-und Werkstoff 63, 204-208.

Kelley, S.W., Turley, L.W., 2001. Consumer perception of service quality attributes at sporting events. Journal of Business Research 54, 161-166.

Kilchling, P., Hansmann, R., Seeland, K., 2009. Demand for non-timber forest products: Surveys of urban consumers and sellers in Switzerland. Forest Policy and Economics $11,294-300$. 
Maldonado, G., Louppe, D., 1999. Les plantations villageoises de teck en Côte d'Ivoire. Bois et Forêts des Tropiques 262, 19-30.

Miranda, I., Pereira, H., 2002. Variation of pulpwood quality with provenances and site in Eucalyptus globulus. Annals of Forest Science 59, 283-291.

Nawir, A.A., Kassa, H., Sandewall, M., Dore, D., Campbell, B., Ohlsson, B., Bekele, M., 2007. Stimulating smallholder tree planting - lessons from Africa and Asia. Unasylva $58,53-59$.

Ngapo, T.M., Martin, J.-F., Dransfield, E., 2004. Consumer choices of pork chops: results from three panels in France. Food Quality and Preference 15, 349-359.

Oliver, R.L., 1980. A cognitive model of the antecedents and consequences of satisfaction decisions. Journal of Marketing Research 17, 460-469.

Pandey, D., Brown, C., 2000. Teak: a global overview. Unasylva 51, 3-13.

Ragaert, P., Verbeke, W., Devlieghere, F., Debevere, J., 2004. Consumer perception and choice of minimally processed vegetables and packaged fruits. Food Quality and Preference 15, 259-270.

Russell, D., Franzel, S., 2004. Trees of prosperity: Agroforestry, markets and the African smallholder. Agroforestry Systems 61-62 (1-3), 345-355.

Santosa, M., Guinard, J.X., 2011. Means-end chains analysis of extra virgin olive oil purchase and consumption behavior. Food Quality and Preference 22 (3), 304-316.

Scherr, S.J., 2004. Building opportunities for small-farm agroforestry to supply domestic wood markets in developing countries. Agroforestry Systems 61-62 (1-3), 357-370.

Shim, S., Eastlick, M.A., Lotz, S.L., Warrington, P., 2001. An online prepurchase intentions model: the role of intention to search. Journal of Retailing 77, 397-416.

Smorfitt, D., Herbohn, J., Harrison, S., 2002. Cabinet-makers' awareness and usage of rainforest cabinet timbers in Queensland. Small-scale Forest Economics, Management and Policy 1 (1), 103-117.

Stiglitz, J.E., 1987. The causes and consequences of the dependence of quality on price. Journal of Economic Literature 25 (1), 1-48.

Taylor, K.A., 1997. A regret theory approach to assessing consumer satisfaction. Marketing Letters 8 (2), 229-238.

Thompson, D.W., Anderson, R.C., Hansen, E.N., Kahle, L.R., 2009. Green segmentation and environmental certification: Insights from forest products. Business Strategy Environment. doi: 10.1002/bse.647. 
UNDP, 2009. Human development report 2009 - Overcoming barriers: Human mobility and development. UNDP, New York. ISBN: 978-0-230-23904-3. 217pp. Online: http://hdr.undp.org/en/reports/global/hdr2009/ (downloaded on 8 November 2010).

Verbeke, W., Vackier, I., 2004. Profile and effects of consumer involvement in fresh meat. Meat Science 67, 159-168. 